\title{
A reinvenção da política na cidade Perspectivas para a governação urbana
}

João Seixas *

\begin{abstract}
$\mathrm{R}$ possíveis novos sistemas de governação da cidade ocidental que surjam neste início de século. Procurando contribuir para uma maior clareza analítica - e mesmo prospectiva perante os desafios com que a governação da cidade de hoje se depara, levantam-se questionamentos que propõem uma perspectiva de conjugação entre o que se denomina de sistema-cidade e sistema de governação de cidade. Sugere-se uma abertura conceptual e analítica em três frentes: a perspectiva de uma maior manifestação sociocultural e institucional das atitudes políticas na cidade; um reforço das capacidades de entendimento desta; a centralização do conceito de governação como conceito sistémico e integrante das diferentes dimensões e valores de acção sociopolítica.
\end{abstract}

Palavras-chave: Cidade; Política Urbana; Governação Urbana.

"Sendo a política um agir livre, tudo pode recomeçar, mas não de qualquer maneira nem em qualquer lugar."

José Bragança de Miranda

presente processo de transformação de paradigma civilizacional, para um pathos cujo carácter crescentemente se assume de índole cultural e urbana, tem colocado a cidade num posicionamento de encruzilhada histórica muito particular: Em texto anterior, procurámos interpretar os padrões urbanos de tais processos de mutação, através da análise de tendências perceptíveis na cidade de hoje: uma nova posição desta no planeta; uma postura político-económica significativamente mais competitiva; uma maior dependência dos elementos e dos vínculos imagéticos e simbólicos; uma estrutura morfológica mais difusa e fragmentada; uma nova personalidade social e identitária; uma alma mais intranquila e desassossegada; e a coexistência de novas com velhas esperanças de reafirmação como esteio civilizacional e cosmopolita (Seixas, 2006).

Não sendo de todo surpreendente, o confronto entre a magnitude dos passos de transformação da cidade, e a dificuldade (por parte dos sistemas político-institucionais e socioculturais vigentes) tanto na sua inteligibilidade (e concomitante capacidade de compreensão de tais mudanças) como no seu necessário acompanhamento (e na construção de respostas de ordem cultural e política) tem deixado muitas vezes instalar-se um panorama global de relativa desorientação cognitiva, e de uma consequente dificuldade de condução estratégica e de acção colectiva. Este é um panorama, não obstante, que tem sido interpretado e enfrentado de formas distintas nas diferentes cidades europeias, constituintes de um amplíssimo universo de múltiplos matizes, e onde as reacções têm sido desencadeadas das mais diversas formas, da quase absoluta passividade, à construção relativamente sustentada de estratégias e de projectos pautados por uma pró-actividade e por um direccionamento consideravelmente concreto no sentido de novas propostas de governação urbana.

\footnotetext{
* Centro de Estudos Territoriais do ISCTE, Lisboa e Universidad Autónoma de Barcelona. Contacto: jseixas@claranet.pt
} 
O que é certo é que, mesmo se para além destas significativas diferenças de percurso, a cidade foi-se tornando, perante a pressão de tais desfasamentos, mais difícil de governar - o que, não obstante, é condição bem diferente de se ter tornado ingovernável - porque cognitiva e politicamente fragmentada, com difícil conjugação de estruturas de responsabilidade colectiva e, demasiadas vezes, sem destino (planeado, pelo menos) bem definido. Apesar de múltiplas acções inovadoras presentemente em desenvolvimento em variadas cidades do planeta, apesar da cidade se encontrar crescentemente reconhecida no seu papel de charneira civilizacional, sociopolítica e ainda ambiental, parece não se detectar ainda, com relativa facilidade, na maioria das urbes, um sentido de visão e de acção política verdadeiramente estratégico e plural, que corresponderá a uma necessidade perene, precisamente, em período de grandes transformações.

Desde sempre lugar central de problemáticas e de potencialidades de nova índole e, por excelência, das riquezas e das turbulências culturais, humanas e relacionais da história, a cidade coloca-se hoje, e de novo, como palco principal e como elemento charneira perante os historicamente inevitáveis - e provavelmente salutares, por processos como o da destruição criativa - desequilíbrios e confrontos inerentes à mudança. Alguns autores, apelando a um novo iluminismo no pensamento político, referem-na mesmo como 'o novo território do político', perspectivando-lhe ainda alguns, com a evolução da globalização e com a recomposição das suas configurações culturais e político-institucionais de governação, a eventual possibilidade de uma 'nova idade de ouro' (Jouve e Lefévre, 2002). Mas, evidentemente, uma série de condições colocam-se como essenciais para, quando muito, melhor conjecturar tais perspectivas. Soja (2000) contrapõe a metrópole moderna - a das tendências actuais, mas gerida apenas por intermédio do urbanismo modernista e com fracas perspectivas políticas e culturais, inovadoras e claras - a uma pós-metrópole, ligada precisamente a um pós-urbanismo que enquadre os novos tipos de realidades e desafios, como o do direito à cidade para todos. Por seu lado, e nas dimensões da cidadania, Jouve (2004) propõe a perspectiva de uma miragem neo-tocquevilliana, pressupondo o aprofundamento das formas e das práticas de concertação, de participação, e de co-responsabilização entre eleitos, administração e sociedade civil (desde os grupos comunitários e associações de diversa índole e escala, aos actores eminentemente económicos). Por outro lado, Clark e Hoffman-Martinot (1998), no âmbito de um longo processo de análise das tendências de evolução sociopolítica de múltiplas cidades espalhadas pelo mundo, têm postulado o paulatino desenvolvimento de uma nova cultura política nos quadros de acção cívica e social, particularmente (mas não só) nas cidades de cariz mais Ocidental. Mas para além das diferentes perspectivas e caracteres mais ou menos realistas, todas estas perspectivas, de uma forma ou de outra, acentuam o recolocar da cidade como ágora política, como grande espaço público, afirmando o seu papel de charneira nos tabuleiros da construção social e política como um todo.

Disse Borja, ainda não há muito tempo: " $A$ cidade é a melhor oportunidade de inovação política. Pela complexidade das políticas públicas que nela se devem integrar, e por uma dimensão que permite uma relação mais directa com a população" (1998, p. 55). Para o estado da arte dos campos do social e do político - e de dimensões tão prementes com o ambiente e a sustentabilidade do planeta - assume óbvia consistência a presente perspectiva, de carácter potencialmente estruturante, de reinvenção da política na cidade - alargando-lhe horizontes, focando-lhe responsabilidades, reestruturando-lhe sistemas, e abrindo-lhe finalmente novas perspectivas de acção e de democracia. Face às perspectivas de se ir paulatinamente deixando as estruturas e os valores de condução do presente e do futuro das cidades quase exclusivamente para lógicas de mercado e/ou ainda (num outro sentido) para lógicas quase exclusivamente tecnocráticas, colocar-se-á a necessidade de rever o que a cidade - e a sociedade urbana - verdadeiramente necessitam e afinal invocam. Talvez, e muito simplesmente, em torno de duas grandes dimensões: primeiro, dos próprios desafios da cidade (sustentabilidade, inclusão social, qualidade de vida, urbanismo qualificado, etc.), que necessitarão de uma orientação política muito clara e que, seguramente, irão implicar a tomada de decisões que contestam algumas práticas e pautas presentes, bem como posicionamentos e privilégios actuais; segundo, dos desafios da própria reafirmação democrática e política, na e com a 
sociedade urbana - permitindo abrir assim novas perspectivas de interiorização e de accionamento dos valores da democracia, da ética e da responsabilidade para cada cidadão.

A leitura de alguns conhecidos estudos de análise comparativa da evolução das cidades europeias (com base na performance de indicadores de qualificação), desenvolvidos nas últimas duas décadas ${ }^{1}$ revela, sem surpresas, uma correlação considerável entre qualificação urbana e inovação política. As cidades com melhores performances e com melhores níveis de qualificação (a vários níveis, social, económico e ambiental, nomeadamente), têm sido também aquelas que, em diferentes situações, cenários e escalas, têm fomentado um determinado grau de inovação e de transformação no panorama das suas políticas urbanas e dos seus próprios quadros político-institucionais.

É por estas linhas, e perante a magnitude e a complexidade dos actuais desafios e das novas oportunidades na cidade, que se coloca como particularmente necessária a construção de uma base conceptual mais consolidada, mas empiricamente bem materializável - portanto, de acção - de reinvenção da cultura e da dinâmica política na cidade. Pois que também aqui se buscam novos paradigmas. Propomos assim, para a parte final deste texto de visão eminentemente conceptual - 'conceptualmente accionável', atrever-nos-íamos a dizer - da política na cidade, algumas reflexões de teor sobretudo ensaístico em torno de três grandes aberturas:

a) Em primeiro lugar, e perante os desafios elevados que se colocam presentemente sobre o seu destino, na basilar necessidade da reinvenção da política na cidade. Recolocando, assim, a polis como objecto central de afirmação política e civilizacional perante o novo paradigma;

b) Em segundo lugar, e tomando precisamente como base o desenvolvimento do novo paradigma cultural, na importância do conhecimento e da formação de padrões de percepção e de entendimento mais claros sobre a cidade contemporânea. Estes, por sua vez, também sob renovadas lentes: quer em termos mais sistémicos e integradores (vendo a cidade como um organismo colectivo, susceptível de tomar opções e de definir estratégias), quer, em simultâneo, em termos mais dinâmicos, mais processuais e assim também mais relacionais (vendo a cidade como uma construção permanente). Como dissemos anteriormente, há que perceber antes de agir;

c) Em terceiro lugar, e baseando-nos na necessidade de reafirmação política, bem como no aprofundamento dos quadros de conhecimento, propondo uma estruturação conceptual e sistémica de acção sociopolítica na e sobre a cidade - o que faremos, de forma certamente sucinta, em torno do conceito-síntese de governação urbana.

\section{O reforço da atitude política na cidade}

São de natureza múltipla os vectores pelos quais se vem recentrando o lugar da cidade, num movimento relativamente oposto ao da sua fragilização:

a) Pela mudança de paradigma histórico, recolocando a cidade e seus principais componentes estruturantes (sua identidade, sua cultura e suas estruturas morfológica, social e económica) como vector civilizacional central;

b) Pelo paulatino evanescimento, em áreas anteriormente centrais da acção colectiva, do papel do Estado-nação, retirando-lhe capacidade de protagonismo e abrindo novos espaços e novos territórios de representação social e de responsabilidade sociopolítica;

c) Pelas grandes transfigurações nas cadeias de valor económico e de poder político, de ordem planetária, estruturadas em importante medida por redes de mais-valias e por estéticas de percepção e de acção, cuja cognição e materialização se encontram profundamente ligadas às novas condições da urbanidade;

d) Pela elevada influência que os modelos e os processos de produção e de reprodução na cidade desencadeiam em essenciais estruturas de sustentabilidade, nomeadamente nas dimensões ambiental e social (estas últimas, de considerável e directo impacto local);

\footnotetext{
1 Vejam-se, nomeadamente, os estudos e análises de Cheshire e Hay (1989), Cheshire (1995), Harding (1996a e 1996b), Kantor, Savitch e Haddock (1997), Borja e Castells (1997), Parkinson (2001), Jouve e Booth (2004).
} 
e) Pelas reconfigurações que têm decorrido nas dimensões sociogeográficas das cidades, bem como nas suas estruturas de cultura, de influência e de poder, conferindo-lhe uma crescente centralidade nos padrões de cognição social e sustentando a emergência de atender às mutações em processo;

f) Pela paulatina afirmação de novas formas de mobilização social, de expressão comunitária, e dos próprios entendimentos e expressões da cidadania - particularmente, perante as novas problemáticas, potencialidades e exigências surgidas nos territórios e nas culturas urbanas;

g) Enfim, pela percepção, persistentemente clara, de que é, afinal, no dia-a-dia de cada indivíduo, comunidade ou empresa, e na sua relação com o ambiente urbano, com as oportunidades e constrangimentos existentes nos espaços e nos tempos vividos, que melhor se sente e pressente a qualidade de vida, a qualidade da democracia e, em termos globais, a qualidade das estruturas sociopolíticas e culturais vigentes.

Sabemos ainda, em simultâneo, que um panorama da cidade como amplo actor, mais estratégico, mais solidário e mais colectivo, consideravelmente estruturado por formas democráticas, plurais e também eficientes, por redes de poder, de administração, de inter-relacionamento e de governança entre os seus diversos actores e instituições, não é um panorama urbano que se encontre facilmente, e se possa dar por adquirido, mesmo após diversas iniciativas políticas e programáticas dirigidas ao fortalecimento das redes de governança urbana. $\mathrm{Na}$ verdade, as paisagens, os recursos e as dinâmicas de governabilidade actuais, bem como as estruturas de capital social e cultural, de muitas cidades europeias, parecem hoje demonstrar importantes deficits - ou desfasamentos - de acção colectiva, nos seus sistemas político-institucionais e nas suas próprias capacidades concretas de governação. Por várias razões, que igualmente temos discutido:

1. Pela emergência de uma miríade de novas realidades e de novas problemáticas na cidade e na metrópole, a que dificilmente se tem conseguido acorrer por via de políticas e de programáticas mais tradicionais e sectorializadas, antes sendo necessárias visões e acções mais integradas, mais multidisciplinares e mais cooperantes;
2. Pela fragmentação dos sistemas político-decisionais, alimentada em importante medida pela incapacidade de reforma das bases sistémicas político-administrativas e, por outro lado, pelo aumento da complexidade das problemáticas urbanas e pela multiplicação das perspectivas, dos agentes e das medidas e acções públicas. Uma fragmentação orgânica, de difícil gestão, provocando dispersão de recursos e de energias e eventualmente dificultando as capacidades de construção de rumos estratégicos mais integrados.

3. Pela persistente vigência de sistemas político-institucionais, e suas estruturas e processos de representação democrática e de decisão pública que, ao não se conseguirem reformar de forma mais consistente nas suas bases (incluindo nas suas bases de domínio), prosseguem uma rota de desfasamento (ou mesmo de afastamento) das necessidades e das potencialidades existentes na cidade do novo paradigma. Longamente consolidados ao longo do último século, estruturados nas suas redes de poder, de responsabilidade e de relacionamento, por uma série de subsistemas e de subculturas de ordem institucional, organizacional, corporativa e ainda político-partidária, os sistemas e respectivos statu quo existentes dificilmente compreenderão uma necessidade de mudança a um ritmo próximo do das transformações que o tempo tem provocado na cidade. Este é um questionamento a colocar, ainda, para as próprias estruturas educacionais e científicas da sociedade, detendo estas, muitas vezes, similares posicionamentos de autodefesa.

4. Por existir, numa importante parte dos espaços de reflexão e de acção mais relevantes sobre os territórios urbanos, um relativamente deficiente entendimento e conhecimento da cidade real e contemporânea, deficiência provocada pela - e que alimenta a - vigência de entendimentos técnico-culturais clássicos (ou modernistas), como os de índole morfo-funcional, que a vêem quase exclusivamente como um corpo (como cidade de sítios), quando muito com determinado tipo de vida, com (algumas) redes (Ferrão, 2003, Font, 2001 e 2003). E, mesmo nestas ópticas, por formas simplistas, demasiado monofuncionais (id.), sustentando-se quase somente num urbanismo de desenho e de infra-estrutura, 
propício às simbologias políticas e estéticas mais simples da orçamentação pública e da competitividade económica, mas afinal com resultados globais distantes da qualificação e da sustentabilidade urbanas. Estas visões têm como base, como temos visto, estruturas de acção político-administrativa e normativa (tanto para o provisionamento público como para a regulação urbanística) de cariz eminentemente clássico, fordista, tratando e regulando cartesiana e sectorialmente acções públicas, usos e ocupações. Deixando, por um lado, escassa margem de envolvimento para outro tipo de entendimentos dos próprios espaços e dinâmicas urbanas (muito nomeadamente em termos dos próprios processos sociais e políticos inerentes às acções); e tolhendo, por outro lado, possíveis dinâmicas governativas mais pró-activas, mais programáticas, e no fundo mais políticas. São ainda muito raras as situações em que os espaços e as dinâmicas urbanas são vistos - e politicamente governados - sob quadros cognitivos sistémica e cientificamente mais abrangentes e plurais.

5. Pela distância do poder face ao cidadão (e vice-versa) e pela dificuldade na abertura à sociedade urbana dos espaços de reflexão e de decisão existentes nos sistemas políticos vigentes, por bloqueio dos grupos mais influentes, comprometendo, em importante medida, o desenvolvimento de uma cidadania (ou de um capital sociocultural na cidade) mais esclarecida e mais empenhada. Um clima de maior proximidade sociopolítica na cidade, para além da abertura dialéctica, deveria permitir o desenvolvimento de projectos e de processos mais plurais e colectivos, mais co-motivantes e co-responsabilizantes entre os diferentes actores da cidade - em ambientes que permitiriam o desenvolvimento, no fundo, das estruturas de base para novos sistemas de acção.

6. Finalmente, e como temos igualmente notado, por se irem transferindo os papéis de principais protagonistas e influenciadores da transformação urbana - em muitas situações, de forma deliberada, numa óptica de favorecimento dos climas, agentes e projectos essencialmente ligados às lógicas da competitividade urbana para determinados actores de produção e de gestão na cidade, provenientes sobretudo de interesses corporativos e privados, cujas estratégias e acções particulares podem não se encontrar minimamente ligadas por qualquer projecto estratégica e colectivamente pensado e co-responsabilizado.

"Há que colocar a política aos serviço da sociedade", escreveu Subirats (2003, p. 7) na sua introdução a um recente trabalho colectivo que procura em simultâneo questionar e sugerir possíveis elementos de nova política em formação nas sociedades contemporâneas. Para este autor, e até recentemente, a equação "população-território-governo representativo" permitia uma razoável conexão entre Estado e Sociedade. Mas efectivamente, nos últimos tempos muita coisa mudou: "hoje em dia temos novas fronteiras, que segmentam a população e as pessoas de novas formas. É necessária uma nova política que opere para reconstruir espaços sociais, donde seja possível refazer os vínculos" (id., p. 8). Assim, “deveríamos ser capazes de construir novas maneiras de entender a política, de maneira a conseguir ir transformando e acabar verdadeiramente superando os modelos burocráticos e hierárquicos" (id., ibid.). Após realçar alguns caminhos por onde se tem procurado fomentar tal construção (nomeadamente os processos de descentralização do poder, e a necessidade de abrir novas pontes e formas relacionais entre o Estado e a Sociedade Civil, com base em determinados valores universais), o autor postula que "reinventar a política quer dizer, portanto, saber construir formas de acção colectiva e formas de gestão institucional, que possam reconhecer a riqueza cultural, humana e relacional da vida social, para que se acabem valorizando, e gerando responsabilidades mais claras sobre os problemas colectivos" (id., p. 9).

Nestes âmbitos, que caminhos, e que conceptualizações, de inovação da política urbana se poderão - e, hoje, se poderão estar a - configurar? Recordemos, neste ponto, alguns dos primeiros questionamentos colocados pelo visionário Lefébvre (1968 e 1970). Perante as mutações na sociedade e na condição urbana, como administrar melhor a cidade? E, ainda antes disso, como a entender melhor, como a visionar melhor, como lhe tomar o pulso colectivo? Como interligar nela, com coerência - particularmente perante os contextos da sua condução política - projecção com decisão, 
forma com processo, espaço com tempo? A modelos de governação urbana suportados por uma longa sedimentação fordista (paradigma da era industrial), deveriam dar lugar novos modelos, baseados agora nas próprias e novas condições da urbanidade. Lefébvre propôs, no final do seu livro sobre a revolução urbana (1970), três leis negativas e três leis positivas:

A. Leis negativas: a) Quebrar as barreiras que dividem e separam o conhecimento e a acção sobre a cidade; b) Acabar com as lógicas de separação e de segregação de pessoas, de funções, de códigos - em suma, acabar com as formas de separação que bloqueiam o desenvolvimento qualitativo; c) Ultrapassar os elementos que provocam a opacidade nos relacionamentos. Subentendem-se, nestas três leis negativas, as fortíssimas críticas de Lefébvre ao urbanismo morfo-funcional da sua época (e em grande medida ainda de hoje), bem mais do que ao facto de este poder ser visto como simples estrutura científico-tecnocrática de suporte às dinâmicas liberais ou neoliberais - para exigir que a promoção do urbano deixe de ser puramente quantitativa, para se tornar eminentemente qualitativa.

B. Leis positivas: a) Substituir, no entendimento e na acção sobre a cidade, a primazia da perspectiva de bem, pela primazia da perspectiva de contrato; b) Assegurar a reapropriação da cidade pelas pessoas; c) Promover a produção e a gestão urbana por novas fórmulas sociais e novas unidades espacio-temporais. Nestas propostas, por sua vez, subentende-se o entendimento da condição e da sociedade urbana, mais como dinâmica ou vida urbana, privilegiando a atenção aos processos dialécticos, aos intercâmbios e às reciprocidades.

Jacobs, profunda crítica dos modelos de planeamento baseados no racionalismo funcional e quantitativo, propôs, por seu lado, três ordens de olhares (1961): (a) Reflectir sobre os processos, ("quando se pensa em processos urbanos, necessariamente se deve pensar nos catalisadores desses processos, os quais são também cruciais", p. 491); (b) Usar a indução; (c) Estar atento às coisas pequenas. A autora, preocupada com a evolução das visões distantes e enviesantes da cidade, pugnou pela instauração nela de valores essenciais, valores como a diversidade e a complexidade, a concentração e a proximidade. Valores que, na verdade, se podem aplicar, por sua vez, tanto aos quadros de regulação e de gestão essencialmente morfológica e urbanística, como às próprias estruturas de relacionamento e de acção sociopolítica e governativa na cidade.

Nos anos mais recentes, uma miríade de processos, de iniciativas, de políticas, acções e programas tem sido desenvolvida, em variadas cidades e territórios urbanos, procurando dirigir-se, cada uma delas por formas mais ou menos inovadoras, para o atender das problemáticas e dos desafios com que se têm que defrontar, em distintas áreas e escalas: a abertura de novas áreas e de novas dimensões de actuação pública e cívica sobre a cidade; o reordenamento institucional de estruturas de responsabilização e de accountability; processos de planeamento urbano e de planeamento estratégico, a várias escalas, por formas social e civicamente mais envolventes e mais co-responsabilizantes; a descentralização de responsabilidades, políticas e programas; o redesenho e reorientação de estruturas normativas e jurídicas; processos de reflexão e de decisão política mais participativos ou mesmo deliberativos; novas experiências de responsabilização comunitária.

Em simultâneo, observando e analisando com atenção as diversas experiências e transformações nos quadros concretos de estratégia e de acção urbana, uma vasta série de pensadores tem procurado desenvolver propostas conceptualmente mais sólidas de estruturação de acções no sentido da reinvenção da política na cidade contemporânea. Borja (2003), para citar apenas um dos mais conhecidos, propõe-nos uma série de áreas a aprofundar: o estabelecimento de cartas de valores e de ideais para a cidade; a consolidação do pensamento e da gestão estratégica; a necessidade das reformas político-institucionais; as concomitantes reorientações formativas e culturais; a primordialidade dos espaços públicos no urbanismo e na dinâmica da cidade; a atenção a elementos mais cognitivos e igualmente de sustentabilidade, como a paisagem; o aprofundamento dos processos e dos espaços para a participação e o envolvimento cidadão; a atenção a novas perspectivas científicas como a economia cognitiva, o urbanismo reflexivo, ou ainda o 'urbanismo cidadão'. 
Entre as principais questões, coloca-se certamente a da necessária interligação, ou pelo menos conjugação dialéctica e potencialmente operacional, da miríade de ideias, críticas e iniciativas. Tanto em termos dos universos do pensamento científico e político, como evidentemente em cada escala local, própria de cada cidade. Se as potencialidades de desenvolvimento de hipotéticos cruzamentos e de formas de integração são claramente visíveis ao nível da discussão conceptual e crítica de ideias e de propostas, para a dimensão bem real de cada cidade estas perspectivas mais colectivas de reflexão, de sistematização conceptual, e de desenvolvimento de estratégias e acções concretas, tornam-se particularmente importantes. Que territórios de questionamento e de desenvolvimento de projectos colectivos e, num sentido mais amplo (porque intrinsecamente mais cultural e também mais quotidiano), de acção mais colectiva, poderão assim ser desenvolvidos na cidade (dado que a fragmentação da acção afigura ser, quase sempre, uma pedra de toque central)?

Perante "alguns embaraços teórico-metodológicos com que nos confrontamos" (Guerra, 2002, p. 47), nomeadamente perante os novos desafios em formação e face a necessárias novas estruturas de entendimento e de acção sociopolítica, esta autora sugere a necessidade de uma atenção a três perspectivas (id.):

a) À necessidade de se entenderem as dinâmicas sociais como processos - seguindo, neste âmbito, as visões de autores das escolas sociológicas francesas, como Crozier e Friedberg (1977), Touraine (1984), ou Gaudin e Novarina (1997), e as aproximações de alguns (poucos) urbanistas (como Jacobs), apontando a importância do entendimento das cidades como sociedades urbanas, em permanente dinâmica e interacção² .

b) Colocando um carácter de urgência na necessidade de construir "uma teoria de acção colectiva, que permita a análise articulada da relação entre o sistema e as racionalidades dos "actores" (p. 48). Ou seja, procurando entender e configurar as pautas e as estruturas globais de relacionamento e de accionamento sociopolítico, de acordo com as estratégias e atitudes dos variados stakeholders na cidade. c) Defendendo uma análise que aproxime, por formas mais articuláveis, precisamente, a teoria da acção. Colocando a tónica nas metodologias de acção e de operacionalização das dinâmicas sociopolíticas na sociedade, baseadas em estruturas de pensamento e de integração estratégica e materializadas em formas mais estruturadas de proximidade, de negociação, de interacção e de reciprocidade. A autora, para além de procurar reposicionar as posturas técnicocientíficas para sentidos mais indutivos e mais sistémicos, procura ainda alavancar conceitos tão vitais como os da governação e do poder, apelando assim às grounded theories para a criação de espaços concretos de acção política - no fundo, para um efectivo e operativo retorno ao político.

Tendo em conta esta desejada busca de "uma maior harmonia entre ciência e acção" (id., p. 51), num quadro de reinvenção da política na cidade, o levantamento das dimensões de enfoque sugere-nos três âmbitos muito concretos de suporte para o seu desenvolvimento: a existência de pautas de valores e de princípios para a cidade; a renovação e revigoração do papel do Estado na cidade (e na política da cidade); e a paulatina inclusão das práticas de cooperação e da expressão da cidadania na cidade e na sua política.

Em primeiro lugar, o reconhecimento mais colectivo do papel central da cidade nos panoramas culturais e civilizacionais, evoca a instauração de pautas de valores e de princípios para ela, através de um forte vínculo simbólico e normativo, tal como uma carta, lei geral ou declaração de princípios. Vínculo discutido e construído de forma aberta e democrática, que assegure à cidade e aos seus cidadãos, precisamente, valores e direitos essenciais: o da cidadania, o da participação, os direitos sociais, a estratégia, o bom governo da cidade, os seus recursos e autonomia, a responsabilidade e a avaliação pública, a eficiência do serviço público, o urbanismo de carácter mais humano, etc. Diversas cidades do planeta têm desenvolvido estes 'pilares constitucionais' (uns mais orientados para princípios gerais, outros para questões político-institucionais muito concretas) e muitos deles têm tido um impacto basilar na sua estruturação e no

\footnotetext{
${ }^{2}$ Relembrando Weber, Lefébvre ou Touraine, mas também diversos outros autores mais recentes.
} 
seu desenvolvimento cultural, social e político. Um exemplo muito interessante e abrangente é o recentemente aprovado Estatuto da Cidade, para as cidades brasileiras ${ }^{3}$. Num âmbito mais institucional, a Carta Municipal de Barcelona é igualmente um interessante exemplo de um enquadramento político e autonómico para a cidade ${ }^{4}$.

Em segundo lugar, e apesar de todos os sinais de crise, de fragmentação e de falta de orientação em diversos sistemas político-institucionais vigentes, há que realçar de novo o papel central das instituições do Estado e dos governos territoriais (e no fundo, também de uma boa e eficiente gestão pública) nos processos de reinvenção da política na cidade. Será essencial não menosprezar o facto - demasiado frequente nos textos mais pós-modernistas sobre temáticas como a da governança - de que as estruturas de governo (ou de soberania) e de administração pública, não obstante o questionamento de alguns dos seus fundamentos, deverão continuar a jogar um papel absolutamente central na condução política da cidade (Jouve e Lefévre, 1999, Hamel, 2004). Ainda para mais quando uma parte considerável dos territórios sob maior expectativa e pressão de transformação se encontrarão, precisamente, no seu seio. Sobretudo, o actor central da cidade, não sendo capturado (ou não se deixando capturar) no seu papel, deverá continuar a ser o governo local. Como realçaremos de seguida, afiguram-se, assim, particularmente importantes os conceitos de governação urbana e de gestão urbana - muito especialmente o primeiro, porque mais integrado e sistémico, embora de todo diminuindo o segundo, mais quotidiano e eficientista, mas que evoca igualmente todos os princípios do bom governo da cidade. Esta atenção sublinha a grande importância do poder e do saber liderar, e particularmente poder e saber liderar em simultâneo com o aprofundamento da democracia, sustentando uma capacidade de tomar decisões em ambientes de pluralidade e de dialéctica. $\mathrm{O}$ sistema de governação da cidade, com as suas dinâmicas, os seus objectivos e os seus múltiplos stakeholdings, necessita igualmente de valores de liderança, de direcção e de gestão, bem como de processos de avaliação e de accountability.

Em terceiro lugar, colocando uma paralela prioridade na valorização das componentes mais dialogantes e cooperantes do capital social e cultural da sociedade urbana ${ }^{5}$. Reivindicando, muito particularmente, a cidadania como expressão maior desse capital, e as lógicas da governança, da cooperação e das parcerias como lógicas de estruturação formal (e, nos seus interstícios, informal) de comunicação e de envolvimento (Healey, 1997, Mayer, 2001). Uma cidadania, assim, potencialmente mais envolvente e mais envolvida nos e com os sistemas de governação da cidade. Mesmo, evidentemente, quando esta se manifeste por vias externas a qualquer estrutura mais formalizada de diálogo e de participação, e ainda por formas de todo assimiláveis por tais estruturas - o que, em si mesmo, não deixará decerto de ser salutar.

\section{O entendimento da cidade}

O reforço e redireccionamento das posturas e das atitudes políticas sobre a cidade pressupõe, evidentemente, uma série de mudanças em diferentes vertentes das suas estruturas socioculturais e político-institucionais cujo carácter não será meramente conjuntural. Implicará, em primeira instância, a necessidade de um mais aprofundado reconhecimento, um mais directo relacionamento cognitivo (diríamos ainda, afectivo) entre o homem e a cidade. Dificilmente se poderá actuar política e culturalmente sobre a cidade actual sem um quadro amplo e (aos olhos de hoje) conceptualmente inovador para a sua compreensão. A atenção ao elemento-cidade, como elemento poliédrico de vivência, de tratamento e de governação, e muito especialmente como palco primordial onde se debate uma série de reptos de futuro, pressupõe portanto a existência de bases mais completas para o seu conhecimento e o seu entendimento. Caleidoscópica por natureza, existindo sobre ela, naturalmente, tantos olhares quanto os possíveis estados de alma de cada indivíduo ou grupo, uma estrutura

\footnotetext{
3 Ver em www.estatutodacidade.org.br e ainda o texto síntese de Júnior e Rolnik (2001).

4 Ver em www.bcn.es.

${ }^{5}$ Em texto posterior, apresentaremos uma proposta conceptual de entendimento do capital sociocultural de uma cidade, no âmbito de seis vectores estruturadores: a configuração e a complexidade socioespacial da cidade; os padrões de identidade e de cultura urbana; os recursos e espaços existentes de informação e de conhecimento urbano; o cosmopolitismo e a envolvência das elites urbanas; as dinâmicas de associativismo e de mobilização cívica; as estruturas e influência das redes de governança.
} 
de acção política que se assuma em paralelo com as suas necessidades e transformações exige certamente novas focagens - e, em muitos casos, novas lentes.

Porém, o 'longo período de desorientação' em torno da cidade e do urbano, de que já falava Lefébvre em 1970, passados mais de trinta anos, existe ainda - e não em pouca medida. Esta desorientação (ou nebulosidade, como alguns também referem) no conhecimento e na interpretação sobre a cidade real, tem dois grandes efeitos nela. Por um lado, tem escamoteado possibilidades de desenvolvimento de caminhos e de processos de transformação mais amplos e mais integrados, mais estratégicos e mais colectivos. Por outro lado, tem permitido a sua fragilização, pela persistente vigência de estruturas e de sistemas político-administrativos e de regulação relativamente desfasados das suas necessidades e potencialidades mais profundas, estruturas que dão muito mais atenção e apoio a modelos, a agentes e a projectos cujas consequências poderão não estar a assegurar padrões de desenvolvimento urbano efectivamente sustentáveis.

Surgem, pois, essenciais, formas e estruturas de inteligibilidade e de cognição da cidade que, ao mesmo tempo que espelhem bem - e amplamente - as suas características simbólicas, identitárias, filosóficas e funcionais (numa perspectiva essencialmente contemporânea), consigam desencadear, nos seus actores urbanos, uma nova sistémica, mais motivacional e mais estruturada, de acção e de dinâmica, tanto cultural como política. Esta necessidade de uma nova inteligibilidade da cidade mostra-se particularmente significativa quando, como temos equacionado ao longo destas páginas, em período de mudanças globais de ordem paradigmática poderem ser perigosamente crescentes os desfasamentos entre os panoramas de acção político-institucional e as múltiplas exigências da urbanidade (e afinal, da própria democracia) - ou, como também escrevemos, a cidade real continuando a afastar-se da cidade política (Seixas, 2002). Para Ferrão (2003), "é este desfasamento entre as características da cidade real e as representações e categorias que sobre ela vamos produzindo que importa esclarecer, de forma a aumentar a nossa capacidade colectiva de a pensar estrategicamente" (p. 222).

Incidiremos a nossa atenção, nestas perspectivas, em torno de determinadas leituras sobre a cidade - ou sobre a sociedade urbana - que nos parecem de especial acuidade. Leituras cuja inspiração e aprofundamento tem advindo de diferentes áreas e de diferentes escolas de pensamento (embora parte importante das suas tónicas se baseie no aumento da 'atenção urbana' por parte das ciências sociais), e que enfatizam, de forma crescente, a necessidade de sistematizar novos quadros de interpretação e de acção sobre a cidade e sobre o urbano. Em termos gerais, e tendo precisamente em conta o nosso objecto central de atenção neste texto - a política e a governação da cidade - situaríamos estas leituras de cidade em duas grandes vertentes de interpretação científica ${ }^{6}$ :

a) Por um lado, apontando a necessidade de afirmar visões mais holísticas e em simultâneo integradoras sobre a cidade, procurando consolidar campos para a sustentação de visões, estratégias e projectos mais globais e mais colectivos. Reconhecendo, também, que a prevalência de perspectivas essencialmente sectorializadas e especializadas sobre a cidade - em certo sentido, também circunscritas e discricionárias - tem-lhe originado, nos tempos mais recentes, consequências de carácter mais dispersivo e insustentável do que se esperaria;

b) Por outro lado, e seguindo uma perspectiva de inspiração weberiana, reavivando as áreas das ciências sociais na sua atenção sobre a cidade - que, na verdade, deve também ser entendida como uma construção social - e colocando assim a tónica nas lógicas e nas dinâmicas de ordem social, nas percepções e identidades, nos processos, estratégias e práticas de actuação dos múltiplos actores e comunidades nela existentes. Reconhecendo que o capital sociocultural e os chamados sistemas de acção de uma cidade se situam, afinal, não somente sob determinadas configurações urbanisticamente desenhadas ou planeadas, mas afirmam-se como estruturas de suporte e de energia quotidiana que alicerça os destinos da cidade.

\footnotetext{
${ }^{6}$ Não fosse esse, ou somente esse, o nosso objecto de atenção sobre a cidade, as possíveis - e certamente necessárias - leituras deste poderiam ser de diversa outra ordem, como a sua interpretação morfológica e estética, a sua condição histórico-cultural ou o seu posicionamento face à sustentabilidade social e ambiental.
} 
Assim, e em primeiro lugar, sigamos precisamente Ferrão, na sua proposta de entendimento da cidade, visando os novos desafios de postura e de acção sobre ela (id.). Uma proposta de inteligibilidade cuja excepcionalidade, no nosso entender, se coloca numa muito interessante conjugação entre uma conceptualização sistémica de natureza holística com uma potencial capacidade de tradução em sistemas concretos de governabilidade e de acção sociopolítica. Numa clara alusão (não escrita) entre a cidade e um ser vivo - muito provavelmente evocando a perspectiva, de todo meramente metafórica, de encarar o sistema urbano como um ecossistema - o autor propõe o entendimento da cidade por intermédio de três grandes ingredientes que personificam o corpo, a vida e a alma.

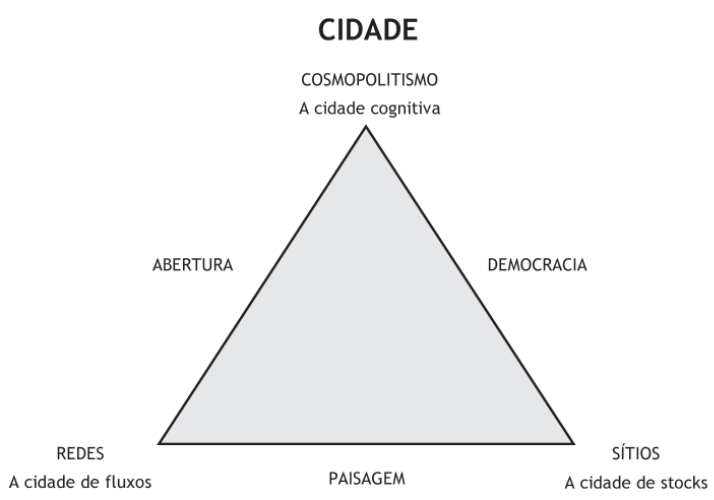

Figura 1 - O triângulo de entendimento da Cidade (Ferrão, 2003)

1. O corpo da cidade são os seus sítios: os solos, os bairros, as avenidas, as ruas, os espaços públicos, as frentes ribeirinhas, os espaços da habitação, de escritórios, de equipamentos ou de comércio. Este é o espaço urbano, nas suas múltiplas escalas, entendido nas suas formas essencialmente clássicas.

2. A vida da cidade é personificada nas suas redes ou fluxos (como o sangue de um ser vivo): as infra-estruturas diversas (com os múltiplos tipos de fluxos que nelas correm), as redes de mobilidade, as redes sociais, os ecossistemas naturais.

3. A alma da cidade e, designadamente, o seu espírito cosmopolita "sustenta a cidade cognitiva, a cidade que pensa, intui e sente" (p. 223). Dá-lhe um sentido, estrutura atitudes e comportamentos, e ainda competências, normas e convenções sociais. Forma-a cultural, social e politicamente, consolida-lhe "uma inteligência colectiva que apenas as cidades parecem conseguir alcançar" (id. ibid.).

Três pilares de valores, que se reforçam reciprocamente, distribuem-se entre estes três elementos. Valores estes, certamente, não menos importantes do que os próprios elementos da cidade, porque afinal são também eles seus constituintes e vínculos basilares de conjunção: paisagem, democracia e abertura.

a. A paisagem da cidade assume-se como o resultado da junção dos seus sítios com as suas redes, sendo "a infra-estrutura que sustenta a cidade cosmopolita". É mais do que uma realidade meramente morfológica: ela traduz em grande medida a sua capacidade de afirmação, o vigor e os sentidos das opções tomadas.

b. A democracia materializou-se na cidade, fundindo a ocupação do espaço com o espírito social humano. Numa cidade saudável, a cidadania democrática surge enriquecida "como resposta às tensões e necessidades que as cidades impõem, mas também às expectativas e ambições dos que aí vivem e trabalham" (id., ibid.).

c. A abertura da cidade mostra as suas condições de acessibilidade, de mobilidade e de conectividade, nas mais variadas dimensões, desde a partilha de informação e de conhecimento, à capacitação e aprendizagem, à disponibilidade multicultural. A abertura da cidade "reflecte, sem dúvida, o potencial de criatividade e inovação que cada aglomeração urbana possui" (id., ibid.).

Embora de evidente complexidade na sua substância, esta é uma estrutura de entendimento que espelha, de forma consideravelmente clara, os inter-relacionamentos entre os elementos e os valores de base com que a cidade se suporta e afirma. O entendimento da cidade como um organismo colectivo coloca-a na natural assunção de tomar opções e de definir estratégias - ou melhor, de definir para si própria um pensamento e uma atitude estratégica - para o seu desenvolvimento. Como tal, esta estrutura de entendimento assume-se igualmente como uma estrutura que permite transmitir um quadro sistémico de acção - social e 
política - condição particularmente premente em tempos de abertura de estratégias, de novas propostas e, precisamente como atrás se pugnou, de uma maior proximidade entre teoria e acção. Uma perspectiva, aliás, com a qual Ferrão de certa forma prossegue o seu texto (id.): "a única maneira de, tirando partido dos grandes valores urbanos, imprimir inteligência e sustentabilidade aos três ingredientes básicos da cidade é através da configuração de sistemas de governança e de financiamento adequados" (id. p. 224).

Atente-se como Viegas (2003) seguiu perspectivas de abertura, de certa forma similares - porque igualmente sistémicas - de entendimento da cidade 7 ao propor que "a política urbanística deva considerar o funcional, o potencial e o imaginário, assegurando a eficácia nos objectos $e$ serviços em que queremos ser apenas consumidores, a versatilidade dos espaços e organizações em que desejamos ser protagonistas, bem como a renovação permanente do sentimento de pertença através do apelo motivador das configurações anunciadas" (p. 263). Este autor refere que, face ao significativo diferencial entre a capacidade de adaptação e de mobilidade dos presentes sistemas de oferta urbana (incluindo os seus sistemas político-administrativos, naturalmente) e as fortes pressões exercidas por parte da procura social e económica, não espanta que se assista a uma produção urbana que se manifesta sobretudo em forma de extensão, mais fácil de organizar e de gerir, também geradora de mais-valias (essencialmente privadas) mais concentradas e a curto prazo (id.).

Em segundo lugar, recordemos um dos principais postulados colocado no início das nossas reflexões, e como as interpretações inovadoras da cidade exigem, igualmente, o seu reconhecimento como sociedade urbana (de novo Weber, 1921 e, evidentemente, Lefébvre, 1970). Neste âmbito, o entendimento dinâmico das estruturas sociais e políticas (no fundo, da própria cidade) coloca-se como elemento charneira para uma visão necessariamente mais ampla e mais atenta das reconfigurações e das problemáticas com que hoje nos deparamos. Para Weber (id.), Benjamin (1999) ou Simmel (1965), reconhecidos pensadores do cosmopolitismo europeu, a cidade é, pela sua própria natureza, o local por excelência de interacção social e, como tal, de revelação social e política. Um anfiteatro privilegiado para a convergência - e para a divergência - de uma miríade de diferentes actores, diferentes entendimentos, diferentes visões e críticas.

Estas perspectivas foram desenvolvidas, nomeadamente, pela escola de Chicago, escola de profícuo pensamento intelectual que aprofundou as estruturas científicas em torno da sociologia urbana e da própria ecologia urbana, estruturas cujas bases permanecem, com efeito, de especial relevância. Seguidas e aprofundadas por diversas outras escolas de pensamento - como a da sociologia francesa dos anos 1970 e 1980, com alguns trabalhos de referência atrás já citados - e parecendo perspectivas conceptuais de índole essencialmente teórico-analítica, estas reflexões abrem a porta, no entanto, a potencialidades de mudança nos próprios enquadramentos de acção social e política, e mesmo de responsabilização científica, sobre a cidade. É, assim, seguindo estas ópticas de reflexão e de conceptualização por via das ciências sociais urbanas, designadamente as ligadas às lógicas e às perspectivas da interacção social, que temos realçado a primordialidade de conceitos como os de cidadania, de capital social, de governança e ainda de actor e de projecto colectivo.

Citaríamos, neste contexto, Harvey (1996, p. 53): "Penso que é necessário reconceptualizar a questão urbana, não como o problema de estudar umas entidades quase naturais, chamem-se cidades, subúrbios, zonas rurais ou o que seja, mas sim como algo de essencial relevância no estudo dos processos sociais que produzem e reproduzem espacio-temporalidades que são, frequentemente, de tipo radicalmente novo e distinto".

Na compreensão e acção sobre a cidade e sobre a sua dinâmica, torna-se assim essencial dar prioridade a um entendimento de processo, para além das visões mais estáticas da forma. As primeiras críticas às visões excessivamente morfológicas e funcionalistas dos espaços urbanos surgem precisamente por via destes questionamentos de índole mais sociológica. $\mathrm{O}$ entendimento por processo, recordemos, era para Jacobs (1961) a

\footnotetext{
${ }^{7}$ Num texto, aliás, inserido na mesma obra (Portas, N., Domingues, A., e Cabral, J., 2003, Políticas Urbanas - Tendências, estratégias e oportunidades, Fundação Calouste Gulbenkian, Lisboa), na sua parte final, que contém textos de análise crítica perante o estado da arte das políticas urbanas e urbanísticas em Portugal.
} 
primeira condição essencial para se perceber e trabalhar sobre a cidade contemporânea. Conceitos que transmitem, como igualmente já referimos, a partir do início da década de 1990, um crescente reconhecimento da passagem de uma consciência fordista para uma outra pós-fordista, onde interacção e processo se tornam, assim (em óbvio diálogo com a forma) elementos-chave de interpretação das linhas de evolução e de gestão urbana, talvez mesmo mais do que muitos dos entendimentos próprios face às instituições, às regras ou aos planos. No campo do planeamento e do urbanismo, nomeadamente, são crescentes as vozes que solicitam um tipo de regulação e de actuação mais substantivo e qualitativo, certamente mais flexível e de controlo menos racionalista ${ }^{8}$.

Noutras diferentes dimensões de observação e de acção sobre a cidade, estas perspectivas parecem igualmente consolidar-se. Refiramos dois breves exemplos. A arquitectura parece estar crescentemente reconhecida em termos de realização estética do lugar de vivência. Para Choay, autora que já escrevera, recordemo-lo, sobre a primordialidade da cidade como construção social, o lugar da arquitectura é muito mais forte e transmissível sob o ponto de vista da construção e não somente da realização (1965). Noutro contexto, os olhares sobre a exclusão social nas cidades têm evoluído para formas distintas do simples conceito de pobreza, para a situarem precisamente em realidades mais dinâmicas, trazendo consigo características de mutação decorrentes dos novos sistemas socioeconómicos; envolve não somente as questões do mercado de trabalho, mas também outras áreas como a habitação; necessita de ser combatida por meio de políticas multisectoriais; e, como tal, tais políticas necessitam de deter uma coordenação integrada e não somente sectorial (Parkinson, 2001).

Para Viegas (2003), "uma parte das relações entre governantes e governados são forçadas a desenvolver-se já não no domínio do poder administrativo, mas sim no da percepção e avaliação da relevância das actuações da outra parte sobre os desígnios do próprio". Embora levantada por uma forma de relação essencialmente causal, sem dúvida que entramos nas dimensões das dinâmicas interrelacionais e dos resultados esperados perante as sinergias destas dinâmicas - ou melhor, no questionamento do relacionamento entre o actor e o sistema.

A interligação entre as perspectivas de maior enaltecimento da cidadania e do capital sociocultural na cidade, e uma série de novas prerrogativas de acção pública, decerto de índole mais racionalista, em torno de campos de acção e de programática política concreta (como a governança urbana ou o planeamento estratégico) parece ajustar-se muito bem a estas propostas conceptuais de entendimento mais sistémico da cidade, bem como nas teorias sociológicas de acção colectiva. Seguindo estas lógicas, o passo seguinte parece ser o de como conseguir conjugar da melhor forma, em processos de dialéctica e de sinergia social (e de construção das próprias políticas públicas), as estratégias, os objectivos e as acções dos múltiplos actores urbanos, no sentido de uma melhor cidade para todos. Retomando o que refere Guerra (2002 e 2006), colocando o cerne das atenções nas perspectivas - tanto teóricas como práticas, através, precisamente, da vital aproximação entre teoria e acção - de gestão dos inter-relacionamentos entre actores e de estruturação de modelos de acção colectiva.

Esta pode também ser compreendida, na verdade, como uma busca que Swedberg (1987) colocou no cerne da 'nova economia política' e que se centra na regulação e na gestão dos conflitos e das sinergias potenciais entre as diferentes partes da sociedade. O que, recordemos, obriga a um renovado papel por parte do actor-Estado e das suas estruturas e configurações de governo e de administração, exigindo-lhe assim uma capacidade de acção mais estratégica e mais perspicaz do que no âmbito das clássicas posturas de liderança de programas e de regulação.

\footnotetext{
${ }^{8}$ O Conselho Europeu de Urbanistas divulgou recentemente a sua nova visão sobre as cidades do século XXI, em documento simbolicamente intitulado ‘A Nova Carta de Atenas' (2003). É proposta, acima de tudo, 'uma cidade coerente'. Para além de chamar a atenção para dimensões como a identidade, a proximidade e a diversidade urbanas, propõe uma maior sensibilidade, na actuação em sede de urbanismo, para os dinamismos económicos e socioculturais e para a sociabilidade na cidade. Sugere, ainda, uma disponibilidade de base para os processos de participação pública e de concertação. Veja-se, a este propósito, críticas e propostas feitas por Portas (1990), Ferreira (2005), Ascher (2001) ou Font (2003). As propostas para a reforma de planeamento urbano, que sirvam melhor a cidade e as suas dinâmicas, são sistematizadas por este último da seguinte forma: a) a separação dos planos de estrutura e dos planos operativos; b) a separação entre planeamento físico e programação; c) a atenção aos procedimentos, à gestão e à participação pública; d) a maior substantividade e flexibilidade dos planos; e) a concepção de um plano como um processo; f) a fundamentação estratégica e hierarquização de prioridades.
} 
Touraine (id.), ao substituir o conceito de sociedade pelo de vida social propôs o conceito de sistema de acção: "O essencial é que a separação crescente do actor e do sistema seja substituída pela sua interdependência, graças à ideia de sistema de acção. Em lugar de descrever os mecanismos de um sistema social, da sua integração e da sua desintegração, da sua estabilidade ou mudança, os sociólogos devem voltar ao estudo de respostas sociais à análise dos mecanismos de autoprodução da vida social" (p. 31). Não obstante a proposta directamente dirigida aos seus colegas sociólogos, as perspectivas de Touraine são obviamente mais globais - e esperançadamente mais actuantes.

\section{A governação urbana}

\section{- quadros de entendimento e de acção}

A exigência do alargamento dos universos de inteligibilidade e das dinâmicas de acção política na cidade, particularmente no âmbito da construção de novos quadros de acção colectiva, obriga-nos, também aqui, a uma revisão de algumas estruturas de pensamento. Procuraremos, para tal, desenvolver uma estruturação conceptualmente sistémica e integrada da acção sociopolítica na e sobre a cidade, em torno de um conceito-síntese, mais abrangente do que os de governo, de governabilidade, de regulação ou ainda de governança: a Governação Urbana. Para Guerra (id.), ao englobar as estruturas, as culturas e as relações de poder e de acção na cidade, a governação permite combinar processos políticos de regulação dos actores e do sistema com a acção pública administrativa (mais institucional e organizacional), mas também com o fomento de uma cultura de emancipação cultural e política para os indivíduos e para os territórios: "A noção de governação inclui e combina o conhecimento de processos políticos de regulação social com compromissos em formas institucionais, organizativas e gestionárias várias" (id., p. 55). Simultaneamente, pode também ser percebido como um sistema integrado de acção - ou seja, de dinâmica comum política e cívica: "a noção de governação apela à existência de objectivos próprios na intervenção pública, que seriam mais do que simples geração de consensos, mas uma real procura de equidade social", implicando "uma perspectiva construtivista (...) uma perspectiva interpretativa pluralista, onde se valorizam os processos de articulação e a capacidade de aprendizagem dos sistemas de acção"” (id., p. 56). Ou seja, governação com processos, claro, mas também com objectivos bem definidos e reconhecíveis. Ou ainda, se quisermos, bem percepcionáveis pelos actores - incluindo o seu próprio papel nos sistemas de acção daí decorrentes.

Por sua vez, Reis (2005), numa análise crítica aos modelos de governação regional em Portugal, elucida desta forma o conceito: "É útil entender por governação o modo como se coordenam instâncias de planeamento, níveis de decisão $e$ lógicas de aplicação das políticas públicas, como se mobilizam a administração e os actores que participam nas políticas públicas, e como se perspectivam os resultados dessas políticas no plano da evolução do conjunto do sistema socioeconómico, tudo isto no quadro de um modelo institucional formado através de decisões explícitas e voluntárias" (p. 41).

A governação pode ser assim epistemologicamente suportada no âmbito de uma conceptualização de sentido integrador e sistémico, colocando-se numa posição de conceito-síntese inclusive perante as próprias perspectivas dinâmicas e processuais de governabilidade. No nosso entender, aquele que poderá ser um dos focos de entendimento mais significativos, coloca-se precisamente nas perspectivas de interligação e de interjunção entre actores, campos e entendimentos diversos, demasiadamente separados por razões de natureza sociocultural. E ainda, na potencial capacidade de uma equilibrada relação entre 'como coordenar', 'como mobilizar', 'como perspectivar' e, ainda, 'como decidir', perante determinados quadros socioculturais, político-institucionais e técnico-científicos. A forma de entendimento e de inter-relacionamento de base sistémica assume, assim, e de novo, particular relevância, abrindo a grande lente e conjugando diferentes níveis, escalas, dinâmicas - e culturas. Sem esquecer, muito pelo contrário, algumas condições também elas essenciais, nomeadamente a posição primordial do actor 'governo local' e das suas 'políticas públicas' (e, da mesma forma, a responsabilidade dos elementos do Estado na perspectiva, na coordenação e na mobilização das estruturas de governação), bem como a imanência do pensamento estratégico e do projecto colectivo, estruturantes ao processo colectivo quotidiano - tanto da cidade como da sua política. 
O sistema de governação da cidade entende-se (e na verdade existe) intrínseco ao próprio sistema-cidade. A reafirmação da política na polis pressupõe uma interligação permanente, uma retroalimentação e reciprocidade de caracteres e de fluxos entre ambos os sistemas. E o projecto colectivo de cidade é, obviamente, um projecto de carácter político e, como tal, emergente do seu sistema de governação (Nel.lo, 2001). Estas perspectivas evocam assim os entendimentos sistémicos da cidade apresentados no ponto anterior. Prosseguindo as perspectivas da proposta de Ferrão (2003) de entendimento da cidade como organismo colectivo, a cidade como organismo político colectivo pode convocar-nos assim, por sua vez, para três elementos, também eles representando corpo, vida e alma: a cidade das instituições, a cidade da governança, e a cidade como capital sociocultural colectivo. Estruturamos assim a nossa proposta sistémica para o contexto da governação na cidade:

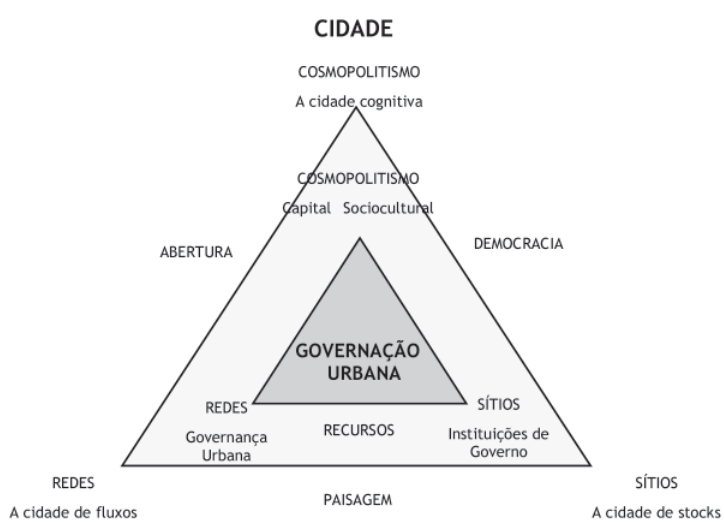

Figura 2 - O contexto da Governação Urbana na Cidade

1. O corpo da cidade política será o seu quadro institucional e organizacional de governo, envolvendo os diferentes órgãos públicos que, pelas mais diversas formas, a governam: câmara municipal, governo regional, freguesias ou distritos urbanos - referindo aqui sobretudo os actores públicos mais clássicos, dado que os universos da acção pública, hoje em dia, incluem formas muito diversas. Apesar da crise manifestada em diferentes vertentes da capacidade de acção e de coordenação político-institucional e governativa sobre a cidade (onde se inclui a própria crise dos sistemas de representatividade), as insti- tuições de governo urbano devem procurar situar-se e agir no âmbito de uma representação em simultâneo simbólica e operacional, que enquadre a complexidade das necessidades da cidade e da sua própria expressão política e democrática, sendo ainda com elas que se reduz muita da incerteza e se contextualizam práticas fundamentais (Reis 2003, Esser e Hirsch, 1994, Healey, 1997 e 1998). As instituições de governo são assim obviamente vitais na própria coordenação e estruturação dos sistemas políticos, e evidentemente dos sistemas de acção política na cidade - mesmo quando (ou especialmente quando) possam ter como um dos seus principais vectores de acção, uma maior partilha de responsabilidade.

2. A vida da cidade política (ou os fluxos de interacção da política) pode ser interpretada pelas suas estruturas e dinâmicas de governança urbana. Relembramos - e repetimos a definição de Bagnasco e LeGalés: "governança define-se como um processo de coordenação de actores, de grupos sociais e de instituições, no sentido de atingir objectivos colectivamente discutidos e definidos, em ambiente fragmentado ou mesmo nebuloso" (2000, p. 26). Em importante medida, a cidade como actor colectivo emerge das redes de inter-relação entre os seus actores (dos empresariais aos ambientalistas, dos institucionais aos sociais), o que implica, em termos concretos, a existência de estruturas de diálogo em diversas escalas: de espaços, instrumentos e mecanismos por onde os fluxos de dialéctica e de cooperação se processem com considerável proximidade, e se desenvolva assim a troca de argumentos e de perspectivas, e a formação de ideias, de consensos, de interdependências e de parcerias, a materializar com consideráveis doses de objectividade e prosseguindo determinados - e consensualizados - fins.

3. A alma da cidade política, ou o seu cosmopolitismo político, afirma-se pela solidez do seu capital sociocultural. É, em simultâneo, a sua identidade e a sua inteligência política colectiva - estruturando-lhe as percepções, os entendimentos, os valores, as atitudes e os comportamentos. Elementos estes, de nature- 
za eminentemente cognitiva, cuja reflexividade nas estruturas culturais e motivacionais de expressão política e cívica, consolidam melhor ou pior a qualidade global do sistema de governação da cidade.

O sistema de governação da cidade situa, igualmente, os valores da paisagem, da abertura e da democracia:

a. A Paisagem na governação urbana enquadra a cidade das instituições de governo e a cidade da governança. Uma boa paisagem de governação necessitará do adequado suporte de recursos e de instrumentos políticos e programáticos, directa ou indirectamente afectos ao governo e à gestão da cidade. Entre estes recursos e instrumentos, deverão encontrar-se tanto elementos simbólicos e normativos basilares tais como pautas de valores e de princípios, como elementos mais operacionais (embora igualmente fundamentais) tais como estruturas de planeamento estratégico e estruturas de competências, bem como adequados recursos humanos e financeiros.

b. A Democracia na governação urbana é fundada nas pautas culturais dos seus valores cívicos e colectivos, e consolida os panoramas institucionais do governo urbano. O cosmopolitismo político da cidade permite, e sustenta, o desenvolvimento de respostas governativas e democráticas - aprofundando-as, se necessário - para as suas problemáticas e para os seus anseios.

c. A Abertura na governação urbana interliga as redes de participação e de governança com as estruturas do capital social e cultural da cidade. Uma governação sustentada numa postura de considerável abertura, proximidade e conectividade nas suas redes e espaços de diálogo e de decisão permitirá uma capacitação dos actores urbanos para um mais aprofundado exercício da cidadania. Consolidando, como tal, os espaços públicos da política na cidade.

Poder-se-á, assim, desenvolver uma muito breve análise crítica do estado da arte da governação da cidade, em torno desta proposta de entendimento sistémico. Os sítios da política da cidade têm sido objecto de diversas transformações nas últimas duas décadas - como vimos, através de processos como a descentralização administrativa ou as mais distintas formas de reorganização institucional. Existe, no entanto, ainda um longo caminho a percorrer quer em termos da sua melhor interligação e paralelismo com os 'sítios' da cidade contemporânea, quer em si mesmo e na sua melhor reestruturação e capacitação (por veículos como uma melhor eficiência ou mais garantidas atitudes de avaliação e de accountability). As redes da política na cidade, por sua vez, são campo com largas expectativas de experimentação e de aprofundamento na reinvenção da política urbana, não obstante as já múltiplas iniciativas que têm vindo a ter lugar pelos mais variados locais, da democracia participativa às mil formas de parceria e de cooperação entre actores. Este é um campo, por sua vez, também pleno de dubiedades e de diferentes matizes, decerto inevitáveis num processo de transformação de índole paradigmática. Até porque as redes da política, sempre tendo existido, quase sempre se basearam na existência de comunidades políticas de âmbito consideravelmente discricionário - e, para o caso de muitas cidades de hoje, mesmo sob formas de regimes estaduais de competitividade e de empreendedorismo (Brenner, 2004), panorama que não parece facilitar a abertura da governação urbana para redes mais fluidas e mais participativas de governança. Finalmente, os espaços da alma na política urbana parecem alimentar-se bem mais do próprio cosmopolitismo da cidade, do que de iniciativas políticas concretas para a sua valorização. Não obstante, é aqui, nas dimensões da cognição, da inteligência colectiva e do capital sociocultural da sociedade urbana que reside o mais precioso capital para a reinvenção da cidade e da sua própria governação.

O que uma análise crítica das transformações dos quadros de acção política na cidade nos últimos vinte anos também mostra, é que, e apesar dessas transformações, parece ainda difícil encontrar processos de mudança que perspectivem a política da cidade por estas - ou por quaisquer outras - formas mais sistémicas, articuladas e inter-relacionáveis. Pelo que, seguramente, um dos principais - senão o principal desafio que se coloca à reinvenção da política na cidade, colocar-se-á, muito simplesmente, na necessidade de verdadeiramente a vermos como um sistema integrado e colectivo. 
Face ao risco da proliferação de espaços vazios, ou de 'terras de ninguém', nos sistemas de governação da cidade - ou então, da sua apropriação por interesses particulares e difusos - hoje, talvez mais do que nunca, mostra-se necessária a construção de Manifestos para a Cidade, pautas de valores, de desígnios e de objectivos. Seguindo a reivindicação do que Nel.lo (2001) chama de 'geografia voluntária': "um exercício de reflexão e de acção colectiva em que a maioria dos cidadãos, de acordo com os seus interesses e o seu espaço de vida, estabelecem os limites entre os quais desejam desenvolver um projecto de vida urbana em comum" (p. 52). Um voluntarismo com o qual as representações e interesses de cada actor, cada escala territorial e questões correspondentes, são expressos e concertados por formas democráticas. Obviamente tal implica a consolidação de um projecto político forte, capaz de enquadrar e gerir o desenvolvimento urbano e os diferentes interesses em benefício da sociedade e do território urbano como um todo, envolvendo por conseguinte um concomitante processo, uma estratégia de coordenação e uma adequada abertura territorial (id.). Estendendo e ampliando o 'debate da cidade', perspectivando e então agindo sobre ele, nas suas mais variadas escalas, vectores e dimensões, num exercício que procurará seguir uma determinada utopia, embora não meramente metafísica. Um verdadeiro projecto colectivo de futuro para a cidade pode assim tornar-se, como sugerimos acima, e para além de pauta global de acção no sentido de resolução das necessidades e dos anseios da sociedade urbana, simultaneamente em recurso e elemento basilar de sustentação do seu capital sociocultural e cosmopolitismo urbano. A sua construção e sustentação necessitarão de uma afirmação política dos actores urbanos, conduzindo a materializações sinergéticas e confirmando a relevância dos processos e das dinâmicas de interrelacionamento, mas solidificando também as estruturas institucionais e as pautas de responsabilidades. Assim se baseando e estruturando, enfim, uma sistémica de acção colectiva.

Reafirmaríamos aqui, e de novo, o essencial papel dos órgãos eleitos, dos governos urbanos e em geral do Estado, nesta ordem de expectativas de evolução. Em primeiro lugar, e muito simplesmente pelo facto de que, em período de carência de respostas numa série de áreas concretas, o
Estado se mantém como principal símbolo e garante - mesmo que em alguns casos, meramente em potência - da estruturação normativa e sociopolítica, e da construção e realização de políticas, na sociedade. E em segundo lugar, pela premente necessidade de avançar - politicamente - por direcções que implicam consideráveis doses de iniciativa e de pró-actividade pública, tais como o maior envolvimento da participação cívica nos processos de reflexão e de decisão; o desenvolvimento de mais alargados sistemas de governança e de partilha de poder; a reconfiguração de estruturas técnico-legais de base (tais como as estruturas normativas de planeamento e de gestão do território ou ainda as estruturas de incidência fiscal sobre a produção e a especulação urbanas); ou, ainda, a reorganização institucional dos próprios sistemas de governo e de administração pública. Tais direcções implicam, ao contrário do que para algumas simplisticamente poderá parecer, uma elevada exigência do papel dos órgãos de governo e do Estado em geral. Na verdade, e em paralelo com o movimento 'do governo das cidades para a governança urbana’ (como LeGalés intitulou, 1995), há também que estar muito atento ao pendular 'da governança urbana para o governo das cidades' (como Jouve e Lefévre igualmente sublinharam, três anos depois, 1999).

O princípio da soberania, apesar de ainda hobbesiano e de raiz moderna, fundamentando-se sobretudo na legitimidade democrática e na capacidade de auto-institucionalização (Duchastel e Canet, 2004) - elementos ainda muito baseados nos poderes delegados essencialmente por lógicas de representatividade - permanece, assim, essencial para a boa regulação política da governação como um todo. Muito particularmente, e numa direcção apenas aparentemente paradoxal, em período de abertura dos espaços de discussão e de responsabilização política. Apesar das crises manifestadas em diferentes vertentes da democracia representativa e dos questionamentos levantados com as graduais entradas em cena de novos co-sistemas, será ainda vital que o princípio da soberania emane e mandate actores que se mantenham capacitados e sólidos o suficiente para uma boa construção e gestão dos sistemas de governação da cidade, nas diferentes escalas (da micro-local à metropolitana/regional); qualificando os espaços de administração, de regulação de 
tomada de decisão; aprofundando o conhecimento sobre a cidade e tomando as decisões necessárias em prol de uma melhor equidade na sua produção e qualificação; construindo e apoiando os espaços de governança; apoiando espaços e dinâmicas catalisadoras da expressão da cidadania e do capital sociocultural na cidade; coordenando e gerindo as regras e as agendas na discussão das iniciativas, das participações e das deliberações mais colectivas. Propondo direcções, entendendo anseios, conciliando estratégias e interesses conjuntos, orquestrando recursos e energias, projectando alianças e, assim, com os demais cidadãos, qualificando a cidade e consolidando-lhe a identidade urbana - e humana - com coesão socioeconómica, sustentabilidade ambiental e criatividade empresarial e cultural. Assim, e tendo o Estado como principal actor estruturante da consolidação de um sistema mais plural e participado, mas também mais perceptível, um novo tipo de soberania, potencialmente mais sólida, poderá desenvolver-se, aprofundando os valores e as instituições da própria democracia na cidade.

Como escreveu Subirats em torno do desenvolvimento de estruturas de participação na cidade (2001): "será básico contar com uma estratégia própria ou projecto, para depois activar a rede, reforçar a densidade de relações entre os seus componentes, favorecendo os pontos de encontro, reduzindo incertezas, gerindo o conflito e facilitando o consenso, na direcção estratégica que a instituição tem planeada. Isso não quer dizer controlar a rede, mas sim orientá-la de maneira mais ou menos consistente com os objectivos que o governo local tenha planeado. A capacidade de liderança da instituição pública dependerá mais da sua capacidade para ser vista pelo resto dos actores como uma garantia de pluralismo, de inclusão social e de gestão estratégica, que da sua pretensa superioridade hierárquica ou monopólio de certos recursos. Definitivamente, o governo local pode enfrentar o seu futuro desde a aceitação da complexidade, assumindo a interdependência entre actores e níveis de governo e reconhecendo que é mais importante resolver problemas e impulsionar políticas que preocupar-se na assignação formal de responsabilidades. Provavelmente poderá defender melhor os interesses colectivos se for capaz de somar esforços, gerar cumplicidades, e acordar vias de avanço, no quadro de opções estratégicas definidas de forma comunitária, aproveitando o valor inelutável da proximidade" (p. 7). Também Santos Silva (2004) realçou as potencialidades de "o Estado (em sentido lato, central e local), confrontando-se com a erosão dos seus poderes tradicionais de regulação, face designadamente à dinâmica da globalização económica, financeira e comunicacional, ver na aproximação ao tecido social uma maneira de recuperar vitalidade" (p. 32).

Colocaríamos, ainda, duas últimas notas de aviso perante os riscos e as esperanças em torno da reinvenção da política na cidade.

Em nosso entender, os maiores riscos podem situar-se em possíveis apropriações de ordem epistemológica. O desenvolvimento de discursos de múltipla índole em torno de palavras como participação, pluralidade, governança urbana ou ainda da própria democracia na cidade, sem um real fortalecimento da sua substância (bem como dos diversos elementos e valores integrantes nos quadros da cidade e da sua governação), é já hoje consideravelmente evidente. Corre-se assim o risco, no universo da inteligência cognitiva em torno das perspectivas de futuro para a cidade, de uma fragmentação ou mesmo esvaziamento, dos significados e dos conteúdos dos grandes valores de base, fragilizando o próprio capital sociocultural da cidade ao retirar-lhe doses de pensamento, de esperança e de motivação.

Em lógica similar, e questionando-nos sobre os potenciais desvios epistemológicos do conceito de governança urbana, os riscos das perspectivas e atitudes excessivamente desconstrutivistas, ou simplisticamente pós-modernistas, podem também ser consideráveis. Para pensadores como Bagnasco e LeGalés (2000), por exemplo, a própria ideia da cidade como actor colectivo pode, não obstante as suas virtudes, deter difícil consistência de efectivação, e tornar-se uma perspectiva demasiado utópica, correndo riscos de reificação (ou de perda de vigor, dada a sua difícil materialidade).

Porém, e não obstante reconhecermos a consistência dos riscos, cremos que estes podem ter especiais condições para a sua consolidação, precisamente quando os horizontes de questionamento e de entendimento sobre a cidade (nos campos técnico-científicos e evidentemente políticos) bem como as suas próprias redes de comunicação e de intercâmbio de perspectivas, e também de 
reciprocidades - se encontram demasiado parciais, sectorializados e especializados. Instalando assim desequilíbrios nas estruturas de pensamento e de acção, necessariamente mais sistémicas e transdisciplinares. O que evoca para uma grande necessidade de diálogo entre os diferentes entendimentos técnico-científicos sobre a cidade. Entre as críticas às vigências excessivamente morfofuncionais e as propostas nas dimensões sociopolíticas, entre as reestruturações político-institucionais e as experiências mais participativas e de co-responsabilização em desenvolvimento, haverá que fazer intersecções e solidificá-las, precisamente, tanto por meio de corpos conceptuais e sistémicos bem estruturados, como através das diversas formas de materialização concreta - e mais colectiva - das aspirações das sociedades e dos territórios. Um efectivo retorno ao político na cidade, evoca assim a essencial concretização de um paralelismo - ou melhor, de um diálogo e de um trabalho mais conjunto e mais profundo - entre as dimensões do morfologico-funcional e do sociopolítico. Ferrão (2004), nomeadamente, realça este diálogo e este trabalho conjunto como, afinal, uma das mais importantes linhas de acção a desenvolver para a redignificação das cidades, através da construção de pontes, da partilha de referenciais e do fomento de projectos e de perspectivas mais interdisciplinares. Se aqui partilhamos de parte importante das críticas ao predomínio da morfo-funcionalidade na visão e na produção da cidade, seríamos, por outro lado demasiado pós-modernistas ao propor a sua simples e desconstrutiva substituição pelo predomínio de uma dialéctica potencialmente etérea, por mais complexa que esta se tornasse, sobre a acção/materialização de objectivos e de decisões. Sendo verdade que a cidade decorre hoje, mais do que nunca, das suas redes, dos seus fluxos e das suas interacções socioculturais e políticas, também não é menos verdadeiro que uma evolução conceptual e operacional vigorosa se deve dar noutros domínios da cidade. Menosprezando-se, por exemplo, as componentes da ética, da responsabili- dade e da eficiência nos sítios da administração pública e do próprio governo urbano, a dispersão inclusive a cognitiva - pode efectivamente tornar-se (ou manter-se) excessiva, podendo potenciar a ocupação dos canais de governança e de desenvolvimento de estratégias, por lógicas e interesses menos colectivos. O entendimento sistémico da governação urbana pressupõe que, em paralelo com o fomento dos espaços e dos processos sociopolíticos de governança, deverão consolidar-se dinamismos políticos nas outras dimensões da cidade e da sua política. É nesse sentido que o utopismo dialéctico proposto por Harvey, nos seus 'espaços de esperança' (2000), é explicitamente espacio-temporal, integrando a forma (espacial, funcional, organizacional) com o processo (social, dialéctico e transaccional).

Muitos dos caminhos de carácter inovador, em desenvolvimento nas mais variadas cidades e nas mais variadas áreas procuram, precisamente, construir e consolidar pontes entre diferentes entendimentos e diferentes perspectivas sobre a cidade. O planeamento estratégico e as estruturas de governança, a microcirurgia urbana e o urbanismo do quotidiano, ou as abordagens cognitivas e criativas, são áreas de trabalho que evocam tal transdisciplinaridade. Colocando também, por esta via, e tal como se pretende para a cidade, determinados actores em diálogo e em confronto. O synekismo ou o 'habitar em conjunto, em proximidade' realçado por Soja (2000) também se aplicará, sem surpresa, à própria expressão da actuação sobre a cidade. Para além da cidade em si, com toda a sua riqueza e o seu fascínio - e que continua a dar-nos, quotidianamente, pequenas e grandes razões para o nosso contentamento e para a sua qualificação - as doses de ética e de motivação potencialmente existentes, respectivamente, nos caracteres de exigência e de utopia das diversas opções a poderem ser tomadas, permitem proporcionar à governação da cidade um capital de esperança muito significativo. 


\section{Referências Bibliográficas}

ASCHER, François (2001) Les nouveaux principes de l'urbanisme, Éditions de l'Aube, Paris.

BAGNASCO, Arnaldo e Le Galès, Patrick (ed.) (2000) Cities in contemporary Europe, Cambridge University Press, Cambridge.

BENJAMIN, Walter (1999) The Arcades Project, Belknap Press of Harvard University Press.

BORJA, Jordi (2003) La ciudad conquistad, Alianza Editorial, Madrid.

BORJA, Jordi (1998) "Ciudadanía y espacio público", in Subirós, P. (ed.) Ciutat real, ciutat ideal-Significat i funció a l'espai urbà modern, Urbanitats n. ${ }^{\circ}$ 7. Centro de Cultura Contemporània de Barcelona.

BORJA, Jordi e Castells, Manuel (1997) Local and GlobalManagement of Cities in the Information Age, Earthscan Publications, Londres.

BRENNER, Neil (2004) "Urban governance and the production of new state spaces in western Europe, 1960-2000", in Review of International Political Economy, 11:3, Routledge, Londres, 447-488.

CHESHIRE, Paul (1995) "A new phase of urban development in Western Europe? The evidence for the 1980's", in Urban Studies, 32 (7), 1045-63.

CHESHIRE, Paul e Hay, David (1989) Urban Problems in Western Europe. An economic Analysis, Unwin Hyman, Londres

CHOAY, Françoise (1965) L'urbanisme, utopies et réalités, Éditions du Seuil, Paris.

CLARK, Terry e Hoffman-Martinot, Vincent (1998) The new political culture, Westview Press, Boulder.

CONSELHO EUROPEU DE URBANISTAS (2003) A nova carta de Atenas 2003 - a Visão do Conselho Europeu de urbanistas sobre as cidades do século XXI, CEU-ECTP, Lisboa.

CROZIER, Michel e Friedberg, Eberhard (1977) L'acteur et le système: les contraintes de l'action collective, Seuil, Paris.

DUCHASTEL, Jules e Canet, Raphael (2004) “Du local ao global - Citoyenneté et transformation des formes de la démocratie", in Jouve, Bernard e Booth, Philip (2004) Démocraties Métropolitaines - Transformations de l'état et politiques urbaines au Canada, en France et en Grande-Bretagne, Presses de L'Université du Québec, Sainte-Foy.

ESSER, Josef e Hirsch, Joachim (1994) "The crisis of Fordism and the dimensions of a 'Post-Fordist' Regional and Urban structure" in Amin, A., Post-Fordism: A reader, Blackwell, Oxford.

FERRÃO, João (2004) “A cidade como agitação social Pedido de ajuda de um geógrafo aos colegas das ciências sociais", in Cidades, Comunidades e Territórios, n. ${ }^{\circ} 8$, 111-117, CET/ISCTE.

FERRÃO, João (2003) "Intervir na cidade: complexidade, visão e rumo", in Portas, N., Domingues, A., e Cabral, J. (coord.) Políticas Urbanas - Tendências, estratégias e oportunidades, Fundação Calouste Gulbenkian, Lisboa.
FERREIRA, António Fonseca (2005) Gestão estratégica de cidades e regiões, Fundação Calouste Gulbenkian, Lisboa.

FONT, Antonio (coord.) (2003) Planeamiento urbanístico De la controversia a la renovación, Diputació de Barcelona.

FONT, Antonio (2001) "Planejament urbanistic per al segle XXI. L'experiencia recent de Catalunya", in Urban, n. ${ }^{\circ} 5$, Madrid.

GAUDIN, Jean-Pierre e Novarina, Gilles (1997) Politiques Publiques et négociation: multipolarités, flexibilités, hiérarchies, CNRS Éditions, Paris.

GUERRA, Isabel (2006) Participação e aç̧ão colectiva. Interesses, conflitos e consensos, Principia, Cascais.

GUERRA, Isabel (2002) "Cidadania, exclusões e solidariedades. Paradoxos e sentidos das "novas políticas sociais"”, in Revista Crítica de Ciências Sociais, 63, Lisboa.

HAMEL, Pierre (2004) "Les villes contemporaines et le renouvellement de la démocratie locale", in Jouve, Bernard e Booth, Philip (2004) Démocraties Métropolitaines - Transformations de l'état et politiques urbaines au Canada, en France et en Grande-Bretagne, Presses de L'Université du Québec, Sainte-Foy.

HARDING, Alan (1996a) The private side of Public-Private partnership: Contrasts and comparisons in European cities, Department of the Environment - Series on Local Government, n. ${ }^{\circ} 3$, Londres.

HARDING, Alan (1996b) Coalition-formation and Urban redevelopment: A cross-national study, full summary of a research project funded by the UK Economic and Social Research Council's Local Governança Programme (1993-1995), European Institute for Urban Affairs, Liverpool.

HARVEY, David (2000) Spaces of Hope, Edinburgh University Press, Edinburgh.

HARVEY, David (1996) "Cities or Urbanisation?" in City. Analysis of Urban Trends, Culture, Theory, Policy, Action 1-2.

HEALEY, Patsy (1998) Institutional Capacity-Building, urban Planning and urban Regeneration Projects, Documento apresentado no congresso da AESOP, Aveiro.

HEALEY, Patsy (1997) Collaborative planning: Shaping places in fragmented societies, Macmillan, Londres.

JACOBS, Jane (1961) Morte e vida de grandes cidades, Martins Fontes, São Paulo (edição de 2000).

JOUVE, Bernard (2004) "Introduction: Le métropoles au croisement de la globalisation et de la transformation du politique", in Jouve, Bernard e Booth, Philip Démocraties Métropolitaines - Transformations de l'état et politiques urbaines au Canada, en France et en Grande-Bretagne, Presses de L'Université du Québec, Sainte-Foy.

JOUVE, Bernard e Booth, Philip (2004) Démocraties Métropolitaines - Transformations de l'état et politiques urbaines au Canada, en France et en Grande-Bretagne, Presses de L'Université du Québec, Sainte-Foy. 
JOUVE, Bernard e Lefèvre, Christian (dir.) (2002) Métropoles ingouvernables: Les villes europeénnes entre globalisation et décentralisation, Elsevier, Paris.

JOUVE, Bernard e Lefèvre, Christian (1999) "De la gouvernance urbaine au Gouvernement des villes? Permanence ou recomposition des cadres de l'action publique en Europe" in Revue Française de Science Politique, 49, 6: 835-853.

JÚNIOR, Nelson e Rolnik, Raquel (2001) "Estatuto da Cidade - novas perspectivas para reforma urbana", Cadernos Polis, Instituto Polis, São Paulo.

KANTOR, Paul, Savitch, Hank e Haddock, Serena (1997) "The political economy of urban regimes: A comparative perspective" in Urban Affairs Review, 32(3): 348-377.

LEFEBVRE, Henri (1970) La révolution urbaine, Editions Gallimard, Paris.

LEFEBVRE, Henri (1968) Le droit a la ville, Anthropos, Paris.

LE GALES, Patrick (1995) "Du Gouvernement des villes à la Gouvernance urbaine" in Revue Française de Science Politique 45 (1): 57-95.

MAYER, Margit (2001) Transformations in urban struggles: from social movement to social capital?, Documento apresentado na conferência The City, Social Justice and Re-distributive Justice, Amsterdam.

NEL.LO, Oriol (2001) Ciutat de ciutats, Editorial Empúries, Barcelona.

PARKINSON, Michael (2001) Key challenges for future urban policy, Documento apresentado na conferência Urban Futures, Estocolmo (ver em www.storstad.gov.se/urbanfutures).

PORTAS, Nuno, Domingues, Álvaro, e Cabral, João (2003) Políticas Urbanas - Tendências, estratégias e oportunidades, Fundação Calouste Gulbenkian, Lisboa.

PORTAS, Nuno (1990) "Urbanismo regrado, urbanismo negociado", in Cadernos Municipais, Ano 2 (53).

REIS, José (Coord.) (2005) Governação regional e gestão das intervenções financiadas pelos fundos estruturais, Estudo efectuado para o Observatório do QCA III (ver em www.qca.pt), FEUC, Coimbra.
REIS, José (2003) Globalização e inovação: uma discussão sobre as densidades urbanas, Texto de intervenção na sessão plenária da conferência "Inovação Tecnológica e globalização: implicações para os países de desenvolvimento intermédio" CET/DINÂMIA (ISCTE), Lisboa.

SANTOS SILVA, Augusto (2004) "Sociedade civil, democracia local e desenvolvimento" in Viegas, José Manuel, Pinto, António Costa e Faria, Sérgio Democracia - Novos desafios e novos horizontes, Celta Editora, Oeiras.

SEIXAS, João (2006) "A cidade na encruzilhada - Novas Realidades e Novos Desafios para a Cidade Europeia Contemporânea" in Cidades, Comunidades e Territórios, n. ${ }^{\circ} 11$ : 105-122, CET/ISCTE, Lisboa.

SEIXAS, João (2002) “The gaps of Urban governance - Questionings and perceptions upon Metropolitan Lisbon urban management", in Cidades, Comunidades e Territórios, n. ${ }^{\circ} 5$ : 99-115, CET/ISCTE, Lisboa.

SIMMEL, Georg (1965) "Les grandes villes et la vie de l'esprit", in Choay, Françoise L'urbanisme, utopies et réalités, Éditions du Seuil, Paris.

SOJA, Edward (2000) Postmetropolis - critical studies of cities and regions, Blackwell Publishers, Oxford.

SUBIRATS, Joan (ed.) (2003) Elementos de nueva política, Centro de Cultura Contemporània de Barcelona.

SUBIRATS, Joan (2001) Ciudad: Proyecto, Gobierno y responsabilidades colectivas, Documento apresentado no Seminari Model Barcelona, Centro de Cultura Contemporània de Barcelona, Outubro.

SWEDBERG, Richard (1987) Current Sociology, Sage Publications, Londres.

TOURAINE, Alain (1984) Le retour de l'acteur, Maspero, Paris.

VIEGAS, José Manuel (2003) "Estratégias Urbanísticas e Governabilidade", in Portas, N., Domingues, A., e Cabral, J., Políticas Urbanas - Tendências, estratégias e oportunidades, Fundação Calouste Gulbenkian, Lisboa.

WEBER, Max (1921) La ville, Aubier-Montaigne (1982), Paris. 